\title{
Article \\ Polyculture of Juvenile Dog Conch Laevistrombus canarium Reveals High Potentiality in Integrated Multitrophic Aquaculture (IMTA)
}

\author{
Yung-Cheng Chang ${ }^{1,2}$, Chia-Huan Ma ${ }^{1,2}$, Hung-Tai Lee ${ }^{3}$ and Te-Hua Hsu ${ }^{1,2, * \mathbb{D}}$ \\ 1 Department of Aquaculture, National Taiwan Ocean University, Keelung 20224, Taiwan; \\ corry0826@gmail.com (Y.-C.C.); booshhoh@gmail.com (C.-H.M.) \\ 2 Center of Excellence for the Oceans, National Taiwan Ocean University, Keelung 20224, Taiwan \\ 3 Department of Environmental Biology and Fisheries Science, National Taiwan Ocean University, \\ Keelung 20224, Taiwan; hungtailee@gmail.com \\ * Correspondence: realgigi@mail.ntou.edu.tw
}

check for

updates

Citation: Chang, Y.-C.; Ma, C.-H.; Lee, H.-T.; Hsu, T.-H. Polyculture of Juvenile Dog Conch Laevistrombus canarium Reveals High Potentiality in Integrated Multitrophic Aquaculture (IMTA). Biology 2021, 10, 812. https://doi.org/10.3390/ biology10080812

Academic Editor: Oswaldo Palenzuela

Received: 27 July 2021

Accepted: 19 August 2021

Published: 22 August 2021

Publisher's Note: MDPI stays neutral with regard to jurisdictional claims in published maps and institutional affiliations.

Copyright: (c) 2021 by the authors. Licensee MDPI, Basel, Switzerland. This article is an open access article distributed under the terms and conditions of the Creative Commons Attribution (CC BY) license (https:// creativecommons.org/licenses/by/ $4.0 /)$.
Simple Summary: The dog conch (Laevistrombus canarium) is a marine gastropod mollusk widely distributed in the Indo-Pacific region. It is an economically crucial species; however, its population has been declining due to overfishing and overexploitation. Hence, we developed a novel polyculture and water-flow method for mass production of this species. Furthermore, the findings from this work also uncover the potentiality of L. canarium in integrated multitrophic aquaculture (IMTA) and its implication for aquaculture and resource restoration.

Abstract: Laevistrombus canarium, also known as dog conch, is a marine gastropod mollusk widely distributed in the Indo-Pacific region. It is an economically crucial species; however, its population has been declining due to overfishing and overexploitation. In this study, the suitable salinity for juvenile L. canarium was between 20 and 35\%. Diatoms and biological detritus by using flow-water from the fish pool were the most favorable diets for newly metamorphosed and $10 \mathrm{~mm}$ juveniles. In the polyculture experiment, L. canarium was cultured with whiteleg shrimp, tilapia, small abalone, purple sea urchin, and collector urchin. Better growth was found in all co-culture groups except with whiteleg shrimp. We also found that the polyculture system with or without substrates significantly affected the growth of juveniles. Additionally, we observed that water temperature was the most crucial factor for growth and survival; a water temperature of less than $10{ }^{\circ} \mathrm{C}$ might cause the death of L. canarium. We have proposed a novel polyculture and water-flow method for mass production of L. canarium and evaluated the feasibility and benefits of polyculture with other species. The findings from this work reveal the potentiality of L. canarium in integrated multitrophic aquaculture (IMTA) and its implication for aquaculture and resource restoration.

Keywords: hatchery; water temperature; salinity; coculture; diatom; breeding

\section{Introduction}

Laevistrombus canarium, commonly known as dog conch, is a marine gastropod mollusk belonging to the family Strombidae. It is widely distributed in the Indo-Pacific region, spanning the south of Japan, the east of India, the Indo-Pacific north of Australia, South Korea, the South China Sea, and Indonesia. The main habitats of L. canarium are the muddy sand bottom, coral sand bottom, and subtidal zone [1,2].

L. canarium is often found in sandy seagrass beds, particularly the seagrass belonging to the genus Halophila. Studies analyzing its stomach contents have reported that it cannot directly eat seaweeds because of its radula shape, and its major food sources are microalgae, filamentous algae, and diatoms present on seaweeds and seaweed detritus [1-4]. Similar ingestion patterns were found in Conomurex luhuanus, a close relative of L. canarium. 
According to the analysis of its stomach contents, L. canarium was reported to feed on tongue-grated particles together with grit and debris [5]. In addition, the study reported that indigestible sand and debris accounted for approximately 75-90\% of its stomach content, whereas algae and diatoms accounting for only $7-15 \%$ of its stomach content that would be its potential sources of energy [5].

L. canarium has a high economic value and is one of the most vital fishery species and staple foods of residents in many coastal areas of Southeast Asia [6]. Currently, the fishing of $L$. canarium is still completely dependent on natural replenishment without aquaculture. However, in recent years, the number of L. canarium has been declining because of overfishing and environmental damage. Therefore, in many countries, resource surveys and management are underway for L. canarium [5-9]. Because they are increasingly scarce, L. canarium is increasingly valuable. The retail price of L. canarium in Taiwan can reach US $\$ 10-15 / \mathrm{kg}$.

The aquaculture of L. canarium is the best approach to preventing its continual overfishing and preserving the natural environment. However, the main food sources of $L$. canarium are yet to be determined, and suitable techniques for its aquaculture have yet to be developed $[1,2,6]$. In our preliminary studies, we did not observe any active feeding behaviors from L. canarium fed by the artificial feed. Alternatively, the algae, biological detritus, and bottom mud were used as the feeds. In commercial farming, providing a large amount of nutritious organic detritus is difficult and expensive to manage $[10,11]$.

Therefore, this study examined the most favorable diets and salinity tolerance for the growth of L. canarium from the larvae, newly metamorphosed, and $10 \mathrm{~mm}$ juvenile stages. In addition, we have developed a novel polyculture system with water flow to provide biological detritus and evaluated the feasibility and benefits of polyculture with other species. The findings of this study can reveal the potentiality of L. canarium in integrated multitrophic aquaculture (IMTA) and its implications for aquaculture and resource restoration.

\section{Materials and Methods}

\subsection{Broodstock and Larval Rearing}

All experiments were conducted in Gongliao Aqua Center, New Taipei City, Taiwan. Broodstocks of L. canarium were collected from the wild (Penghu island, Taiwan) and reared in a tank-based flow-through system $(2500 \mathrm{~L}$ round fiberglass reinforced plastic (FRP) tanks). Broodstocks were fed once a day at 17:00-18:00, and leftover feed and dead individuals were removed before feeding. Commercial tilapia feed ( $24 \%$ protein) and sea cucumber feed (34\% protein) was used in the preliminary diets test. The amount of daily feed was equal to $5 \%$ of body weight for L. canarium. However, we did not observe active feeding behavior. Diatoms and other biological detritus produced by feed may be their main source of nutrients.

During the breeding season (May to September), broodstocks $(n>250)$ were randomly mated and laid egg capsules at the bottom. Egg masses were collected and placed in plastic baskets with a mesh size of $0.5 \mathrm{~cm}$ and subsequently submerged in an adequately aerated hatching tank. Seawater was replenished daily until hatching. The rearing and culturing methods used were according to those reported by Cob et al. [7]. After hatching, swimming veligers were collected using a $50 \mu \mathrm{m}$ mesh net and then transferred into $2500 \mathrm{~L}$ round FRP tanks at a concentration of 100 larvae/L. Natural seawater filtered using a $1 \mu \mathrm{m}$ filter and mild aeration was used. The salinity and temperature of larval culture seawater were maintained at $34 \pm 1 \%$ and $28 \pm 1{ }^{\circ} \mathrm{C}$, respectively; larval culture was maintained under 12:12 h light-dark conditions. Seawater was exchanged every 2 days with freshly filtered (using a $1 \mu \mathrm{m}$ filter) natural seawater. L. canarium veliger larvae were fed the alga Isochrysis galbana and Tetraselmis chui at 1000 cells/mL once a day throughout the culture period. Fourteen days after hatching, the larvae of L. canarium developed to stage IV veliger that had a six-lobed velum that was considerably elongated with a finger-like appearance [7] (Figure 1). The individual with a well-developed proboscis and a dark green pigment at the 
later stage was subsequently moved into 2000 L FRP tanks for cultivation. Diatom-attached plastic plates were used to induce metamorphosis in seedlings and function as a part of the initial diet. Seedlings present at the sinking bottom were fed natural diatoms.

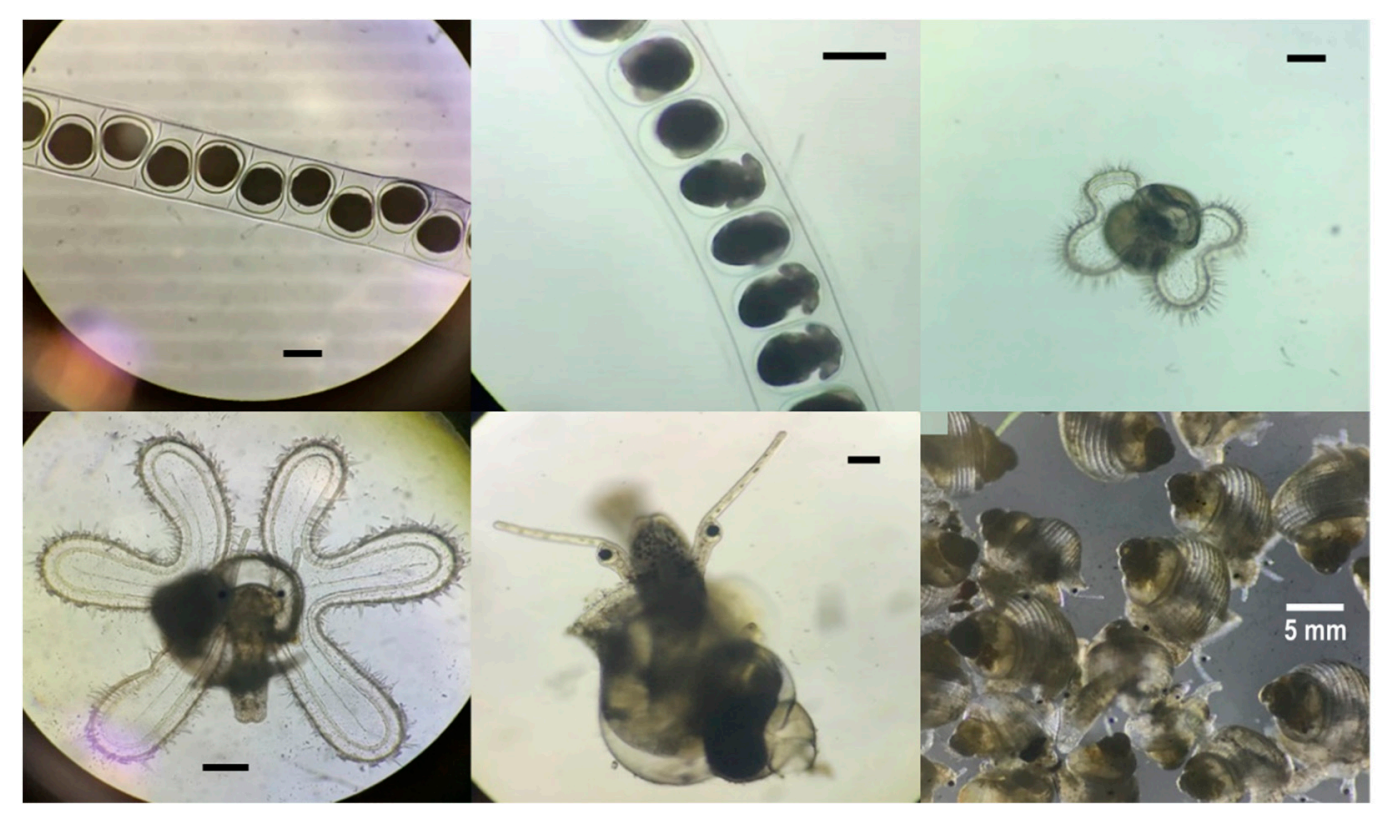

Figure 1. The development stages of Laevistrombus canarium. Egg capsules (top left); embryo (top center); 4-lobed veliger (top right); 6-lobed veliger (bottom left); newly metamorphosed juveniles (bottom center) (Scale bar $=100 \mu \mathrm{m}) ; 10 \mathrm{~mm}$ juveniles (bottom right) (Scale bar $=5 \mathrm{~mm}$ ).

\subsection{Salinity Tolerance}

Salinity tolerance experiments for stage II veligers [7] and newly metamorphosed juveniles were conducted in $5 \mathrm{~L}$ beakers containing $3 \mathrm{~L}$ of seawater. The beakers had different salinity levels $(35,30,25,20,15$, and 10\%o), and all experiments were performed in triplicate. A total of 300 veligers and 50 juveniles were placed in each beaker for $0-96 \mathrm{~h}$ and 0-30 days, respectively. The culture seawater was maintained at a temperature of $28 \pm 1{ }^{\circ} \mathrm{C}$ under 12:12 h light-dark conditions. To enable the continual movement of larvae, all beakers were mildly aerated. At $0,24,48,72$, and $96 \mathrm{~h}$ of the experiment for veligers and at $0,1,2,15$, and 30 days for juveniles, each sample was examined under a dissecting microscope, and larvae were evaluated to be swimming or dead. Larvae that were lying at the bottom of the container but were capable of swimming if distributed were considered as being alive.

\subsection{Diet Experiments}

\subsubsection{Newly Metamorphosed Juveniles (1 mm)}

Diet experiments for newly metamorphosed juveniles were conducted in $5 \mathrm{~L}$ beakers containing $3 \mathrm{~L}$ of seawater. The groups were fed natural diatoms, sea cucumber feed (Omaga sea cucumber artificial feed; Chuan Kuan Enterprise, Kaohsiung, Taiwan), Thalassiosira weissflogii (TW1800; Reed Mariculture, Campbell, CA, USA), Thalassiosira pseudonana (TP1800; Reed Mariculture, Campbell, CA, USA), and kelp powder (Omaga seaweed powder; Chuan Kuan Enterprise, Kaohsiung, Taiwan). The nutrient composition of kelp powder was as follows: crude protein $12 \%$, crude Ash $15 \%$, moisture $11 \%$, crude fat $0.4 \%$, and crude fiber $14 \%$. Nutrient composition of sea cucumber feed is as follows: crude protein $34 \%$, crude Ash $15 \%$, moisture $9 \%$, crude fat $2.5 \%$, crude fiber $4 \%$, and $\mathrm{HCl}$ insoluble $1.8 \%$. T. weissflogii and T. pseudonana were live and highly-concentrated commercial products (algae). They were stored at $4{ }^{\circ} \mathrm{C}$ and used up within four weeks. Additionally, an extra experiment was conducted in outdoor tanks $(240 \mathrm{~L}, 90 \times 60 \times 45 \mathrm{~cm})$ supplied with flow water from a 2,000,000 L concrete pool (Figure 2A). All experiments were performed in 
triplicate. The amount of daily feed was equal to $5 \%$ of the body weight of juveniles. A total of 100 juveniles were placed in each beaker for 30 days for each group. The salinity and temperature of culture seawater were maintained at $34 \pm 1 \%$, and $28 \pm 1{ }^{\circ} \mathrm{C}$ under $12: 12 \mathrm{~h}$ light-dark conditions. To maintain an adequate level of dissolved oxygen, all beakers were mildly aerated. Seawater was exchanged every day with freshly filtered (using a $1 \mu \mathrm{m}$ filter) natural seawater. At $0,7,14,21$, and 30 days into the experiment, each sample was examined under a dissecting microscope, and juveniles were examined to determine if they were alive or dead.

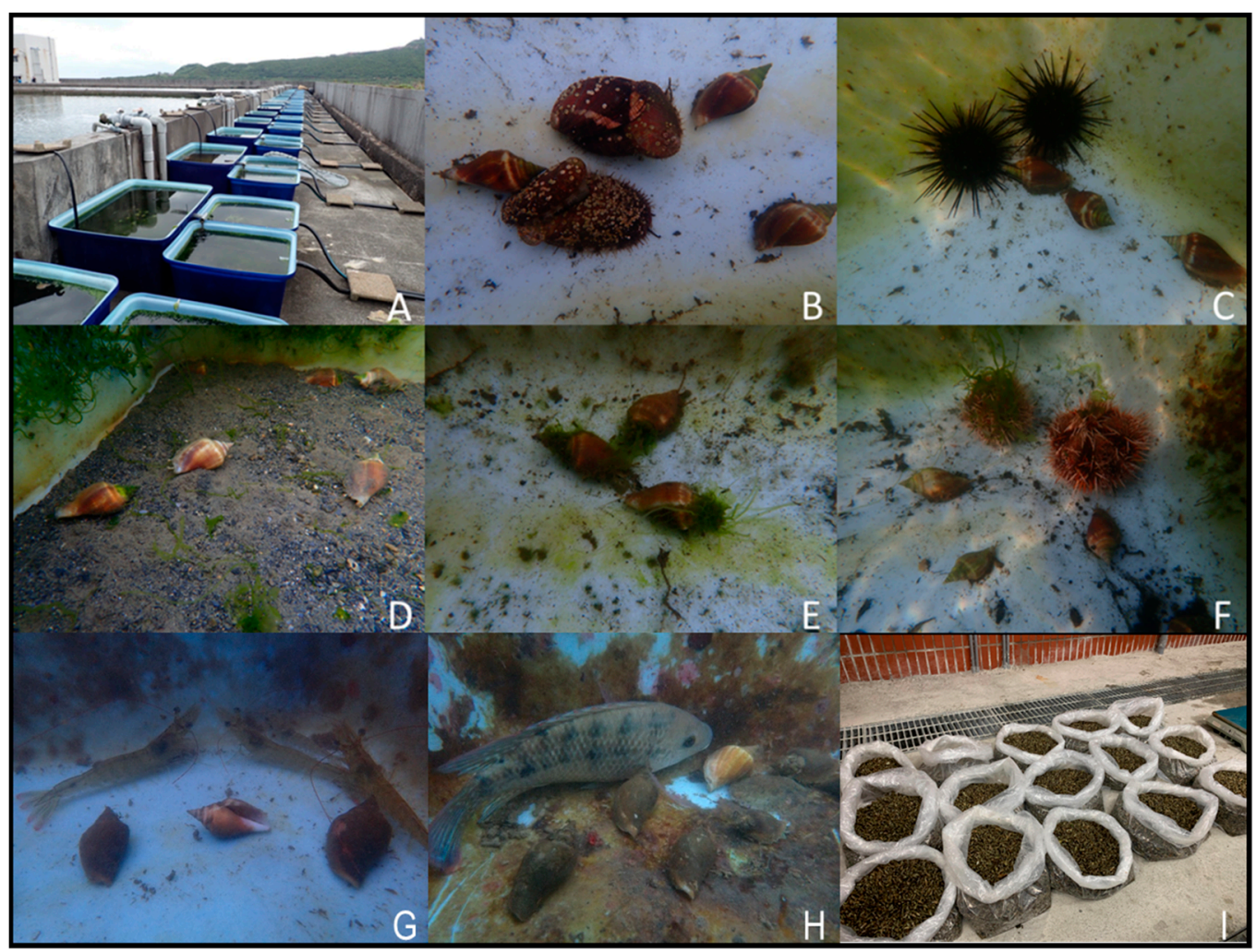

Figure 2. The experiment of juvenile Laevistrombus canarium cocultured outdoor with different species. (A) plastic tank: $60 \times 45 \times 90 \mathrm{~cm}$; (B) abalone Haliotis diversicolor; (C) purple sea urchin Anthocidaris crassispina; (D) with sands; (E) control; (F) collector urchin Tripneustes gratilla; (G) shrimp Litopenaeus vannamei; (H) tilapia Oreochromis mossambicus; (I) mass production of juveniles in the Gongliao Aqua Center.

\subsubsection{Juveniles $(10 \mathrm{~mm})$}

Diet experiments for $10 \mathrm{~mm}$ juveniles were conducted in $10 \mathrm{~L}$ tanks containing $8 \mathrm{~L}$ of seawater. The groups were fed natural diatoms, sea cucumber feed, and kelp powder, and all experiments were performed in triplicate. The amount of daily feed was equal to the $5 \%$ of the body weight of juveniles. A total of 30 juveniles were placed in each tank for 56 days for each group. The experimental condition and an extra outdoor experiment were the same as Section 2.3.1 Newly metamorphosed juveniles. At 0, 7, 14, 21, 28, 35, 42, 48, and 56 days of the experiment, each sample was examined under a dissecting microscope. Juveniles were examined to determine whether they were alive or dead. While their body weight was regularly measured, their shell length (SL), width (SW), and depth (SD) were only measured on the final day of experiments (the 56th day) due to the limit of their small body size.

\subsection{Indoor Polyculture Experiments}

Polyculture experiments were performed using juveniles in $16 \mathrm{~L}$ tanks $(30 \times 55 \times$ $10 \mathrm{~cm}$ ) at $18{ }^{\circ} \mathrm{C}$ and $28^{\circ} \mathrm{C}$. The groups were either monocultured (cultured without sand 
as the control and cultured with sand) or cocultured with shrimp Litopenaeus vannamei, tilapia Oreochromis mossambicus, abalone Haliotis diversicolor, purple sea urchin Anthocidaris crassispina, and collector urchin Tripneustes gratilla. Clean and dry sand was used in the beginning. All experiments were performed in triplicate. A total of 30 juveniles (SL: $16.5 \pm 1.2 \mathrm{~mm}$ and weight: $0.34 \pm 0.08 \mathrm{~g}$ ) were placed in each tank for 90 days for each group. The total body size of cocultured species was larger than that of L. canarium to ensure that it received adequate food sources (fecal matter from coculture species). The size of coculture species was $3 \mathrm{~cm}$ (shrimp), $5 \mathrm{~cm}$ (tilapia), $2 \mathrm{~cm}$ (abalone), $2 \mathrm{~cm}$ (purple sea urchin), and $2.5 \mathrm{~cm}$ (collector urchin). The amount of daily feed was equal to $5 \%$ of the body weight of the cocultured species. Commercial shrimp feed (50\% protein) was used in shrimp coculture groups; commercial tilapia feed ( $24 \%$ protein) was used in tilapia coculture groups; and commercial sea cucumber feed (34\% protein) was used in abalone, purple sea urchin, and collector urchin coculture groups. The salinity and temperature of culture seawater were maintained at $34 \pm 1 \%$ and 18 or $28 \pm 1{ }^{\circ} \mathrm{C}$ under a $12: 12 \mathrm{~h}$ light-dark condition. To ensure an adequate level of dissolved oxygen, all tanks were mildly aerated. A recirculating aquaculture system was used, and $80 \%$ seawater was exchanged every 2 days with freshly filtered (using a $1 \mu \mathrm{m}$ filter) natural seawater. At 0,15 , $30,45,60,75$, and 90 days into the experiment, each sample was examined by the naked eye to determine whether they were alive or dead. Various linear morphological characteristics of the shell were measured to a precision of $0.01 \mathrm{~mm}$ by using a digital vernier caliper. The measurements included SL, SW, and SD. All the procedures were conducted in accordance with ethical guidelines governing research using animals for in vivo experiments.

\subsection{Outdoor Polyculture Experiments}

Outdoor polyculture experiments for juveniles were conducted in 240-L tanks $(90 \times 60 \times 45 \mathrm{~cm})$ (Figure 2). The groups (monoculture and coculture) were the same as Section 2.4. Indoor polyculture experiments. A total of 30 juveniles (SL: $16.5 \pm 1.2 \mathrm{~mm}$ and weight: $0.34 \pm 0.08 \mathrm{~g}$ ) were placed in each tank for 270 days for each group. The total body size of the coculture species was larger than that of L. canarium to ensure that. it received adequate food sources (feces from coculture species). The sizes of the coculture species and their feed were the same as Section 2.4. Indoor polyculture experiments. The flow-through system was used. The salinity of natural seawater was between 28 and $34 \%$, and its temperature ranged from 7 to $32{ }^{\circ} \mathrm{C}$ (the highest and lowest temperature recorded during September to June). To maintain an adequate level of dissolved oxygen, all tanks were mildly aerated. At $0,30,60,90,120,150,180,210,240$, and 270 days into the experiment, each sample was measured as Section 2.4. Indoor polyculture experiments.

\subsection{Statistical Analysis}

The statistical analysis was conducted in SPSS 19 (IBM, Armonk, NY, USA), and the results are presented in terms of the mean \pm standard deviation. All the data were verified to the normal distribution by Shapiro-Wilk test $(\alpha=0.05)$. The data were subjected to one-way analysis of variance (ANOVA) and Tukey's honestly significant difference post hoc multiple range test (Tukey's HSD) to examine differences between treatments.

\section{Results}

\subsection{Salinity Tolerance}

Table 1 lists the results of the tolerance of L. canarium (stage II veligers and newly metamorphosed juveniles) to salinity. The survival rate of the stage II veliger groups exposed to $25-35$ salinities was $98-100 \%$ until the end of the experiment (not significant). The aforementioned three groups could normally metamorphose to veliger stage III (Figure 1). The survival rate of the groups exposed to below 20 salinities decreased to 80,15 , and $10 \%$ after $24 \mathrm{~h}$, respectively, and all veligers died after $96 \mathrm{~h}$. The vigor of living seedlings exposed to 15 and 10 salinities was poor, and only the cilia were observed to be moving (they swung limply and did not swim). The survival rate of the juvenile groups exposed to 35, 
30, 25, and 20 salinities was $100 \%$ after 30 days (Table 1 ). The aforementioned four groups could grow normally (Figure 1). The survival rate of the group exposed to 15 salinities was $72 \%$ at 15 days and $47 \%$ at 30 days. Furthermore, the survival rate of the group exposed to 10 salinities decreased to $6 \%$ after $24 \mathrm{~h}$, and all juveniles died after $48 \mathrm{~h}$. The vigor of living juveniles exposed to 15 and 10 salinities was poor.

Table 1. Survival rates (\%) of veligers and newly metamorphosed juveniles of Laevistrombus canarium exposed to different salinity levels.

\begin{tabular}{ccccccc}
\hline Veligers & Salinity & $\mathbf{0}$ & $\mathbf{2 4} \mathbf{h}$ & $\mathbf{4 8} \mathbf{h}$ & $\mathbf{7 2} \mathbf{~ h}$ & $\mathbf{9 6} \mathbf{~ h}$ \\
\hline & 35 & 100 & $100^{\mathrm{a}}$ & $100^{\mathrm{a}}$ & $100^{\mathrm{a}}$ & $100^{\mathrm{a}}$ \\
& 30 & 100 & $100^{\mathrm{a}}$ & $100^{\mathrm{a}}$ & $100^{\mathrm{a}}$ & $100^{\mathrm{a}}$ \\
& 25 & 100 & $100^{\mathrm{a}}$ & $100^{\mathrm{a}}$ & $99^{\mathrm{a}}$ & $98^{\mathrm{a}}$ \\
& 20 & 100 & $80^{\mathrm{b}}$ & $48^{\mathrm{b}}$ & $19^{\mathrm{b}}$ & $0^{\mathrm{b}}$ \\
& 15 & 100 & $15^{\mathrm{c}}$ & $0^{\mathrm{c}}$ & $0^{\mathrm{c}}$ & $0^{\mathrm{b}}$ \\
\hline Juvenile & 10 & 100 & $10^{\mathrm{d}}$ & $0^{\mathrm{c}}$ & $0^{\mathrm{c}}$ & $0^{\mathrm{b}}$ \\
\hline & salinity & $\mathbf{0}$ & $\mathbf{2 4} \mathbf{h}$ & $\mathbf{4 8} \mathbf{h}$ & $\mathbf{D a y ~ \mathbf { 1 5 }}$ & $\mathbf{D a y ~ 3 0}$ \\
& 35 & 100 & $100^{\mathrm{a}}$ & $100^{\mathrm{a}}$ & $100^{\mathrm{a}}$ & $100^{\mathrm{a}}$ \\
& 30 & 100 & $100^{\mathrm{a}}$ & $100^{\mathrm{a}}$ & $100^{\mathrm{a}}$ & $100^{\mathrm{a}}$ \\
& 25 & 100 & $100^{\mathrm{a}}$ & $100^{\mathrm{a}}$ & $100^{\mathrm{a}}$ & $100^{\mathrm{a}}$ \\
& 20 & 100 & $100^{\mathrm{a}}$ & $100^{\mathrm{a}}$ & $100^{\mathrm{a}}$ & $100^{\mathrm{a}}$ \\
& 15 & 100 & $100^{\mathrm{a}}$ & $100^{\mathrm{a}}$ & $72^{\mathrm{b}}$ & $47^{\mathrm{b}}$ \\
& 10 & 100 & $6^{\mathrm{b}}$ & $0^{\mathrm{b}}$ & $0^{\mathrm{c}}$ & $0^{\mathrm{c}}$ \\
\hline
\end{tabular}

Veligers: stage II veligers according to Cob et al. [7]. ${ }^{\mathrm{a}, \mathrm{b}, \mathrm{c}, \mathrm{d}}$ Values in rows with different lowercase letters indicate significant differences (Tukey's HSD; $p<0.05$ ).

The tolerance and suitable salinity range of L. canarium become wide with the growth stages. Occasionally, the salinity is down to $15-20 \%$ after heavy rains. We could found a significant negative effect on veligers and moderate on newly metamorphosed juveniles. However, no abnormal behavior of the broodstock was observed.

\subsection{Diet Experiments}

\subsubsection{Newly Metamorphosed Juveniles (1 mm)}

Figure 3 presents the survival rate of the newly metamorphosed juvenile L. canarium fed with different diets. The mean survival rates of groups fed with natural diatoms, sea cucumber feed, T. weissflogii, T. pseudonana, and kelp powder were 81.5, 74.5, 68.4, 60.5, and $0 \%$, respectively, until the end of the experiment. The aforementioned four diet groups, except for the kelp powder group, could grow normally. The highest mean survival rate $(90.5 \%)$ was observed in extra outdoor tanks with flow water from the fish pool. Although natural diatoms were also collected from the fish pool in the diet experiment, the flow water system can continuously provide diatoms and other biological detritus, and to get a better survival rate.

\subsubsection{Juveniles $(10 \mathrm{~mm})$}

Figure 4 and Table 2 show the weights of the $10 \mathrm{~mm}$ juvenile L. canarium fed with different diets and extra outdoor group. The final weights of groups fed with natural diatoms, sea cucumber feed, kelp powder, and flow-water were $0.46 \pm 0.21,0.82 \pm 0.16$, $0.15 \pm 0.25 \mathrm{~g}$, and $1.01 \pm 0.51$, respectively. The survival rates were $100 \%$ except for kelp powder $(76 \%)$. The weight, SL, SW, and SD significantly differed among the groups $(p<0.05 ;$ Table 2). Natural diatoms are good in the first 28 days, however, their nutrition might not be enough for growth after 28 days ago. On the other hand, sea cucumber feed is not best in the first 28 days, however, their nutrition is enough for growth after 28 days ago. It is the same as Section 3.2.1. Newly metamorphosed juveniles, the highest survival rate and weight $(100 \%$ and $1.01 \pm 0.51)$ were observed in the extra outdoor tanks with flow water from the fish pool. It means Diatoms and biological detritus from the fish pool can 
provide enough diets with good nutrition for newly metamorphosed juveniles to at least $25 \mathrm{~mm}$.

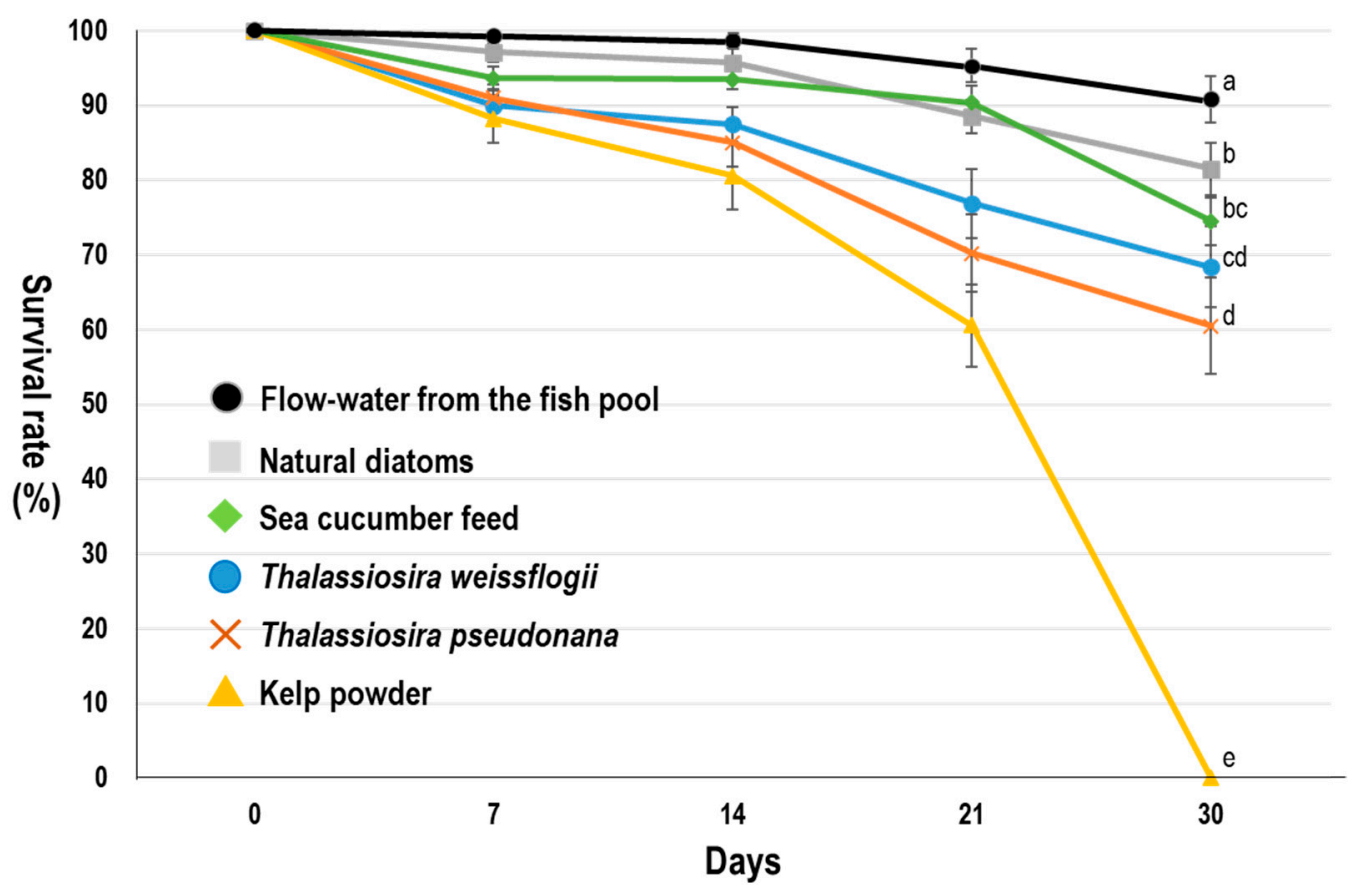

Figure 3. Survival rates of newly metamorphosed juvenile Laevistrombus canarium fed with different diets. The data of flow water from the fish pool were from outdoor tanks. We use $240 \mathrm{~L}$ tanks $(90 \times$ $60 \times 45 \mathrm{~cm}$ ) for juveniles and use flow-water from the 2000 tons fish pool (Figure 2A). Groups show significant differences by the 30th day (ANOVA; $p<0.001$ ). Lowercase letters indicate significant differences (Tukey's HSD; $p<0.05$ ) of examined variables between diets. Bars present the mean \pm standard deviation.

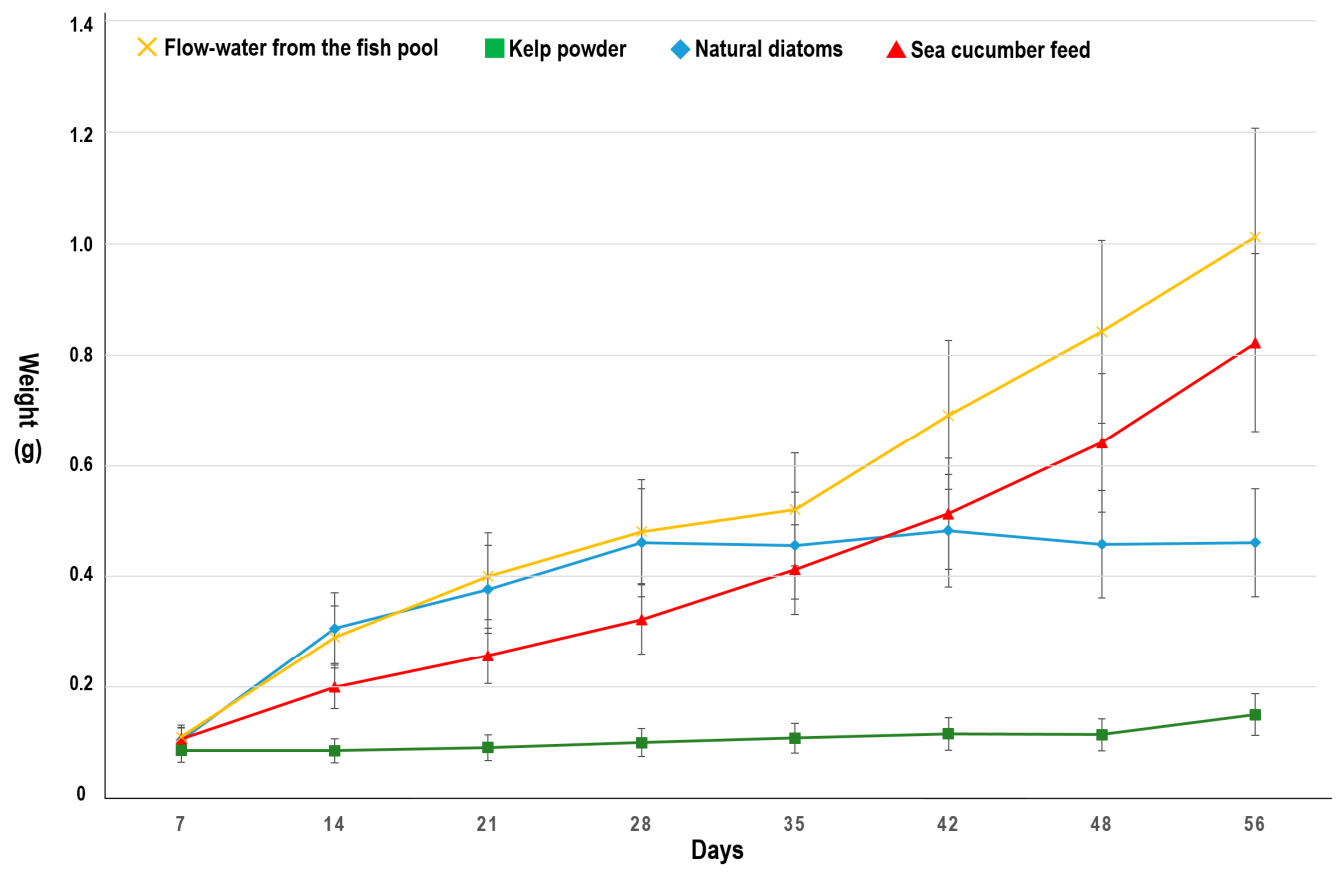

Figure 4. Laevistrombus canarium. Mean ( $\pm \mathrm{sd}$ ) weight of $10 \mathrm{~mm}$ juveniles at various sampling during 56 days of feeding on four diets (flow water, natural diatoms, sea cucumber feed, kelp powder). 
Table 2. Laevistrombus canarium. Mean ( \pm sd) values of weight, shell length, shell width, shell depth, survival rate, and daily growth rate of $10-\mathrm{mm}$ juveniles after 56 days of feeding on four diets (flow water, natural diatoms, sea cucumber feed, kelp powder).

\begin{tabular}{cccccc}
\hline Parameter & Flow-Water & $\begin{array}{c}\text { Natural } \\
\text { Diatoms }\end{array}$ & $\begin{array}{c}\text { Sea Cucumber } \\
\text { Feed }\end{array}$ & Kelp Powder & $p$ \\
\hline SL (mm) & $25.65 \pm 4.75^{\mathrm{a}}$ & $18.09 \pm 2.10^{\mathrm{b}}$ & $20.89 \pm 3.79^{\mathrm{c}}$ & $11.73 \pm 2.35^{\mathrm{d}}$ & $* * *$ \\
SW $(\mathrm{mm})$ & $12.49 \pm 2.51^{\mathrm{a}}$ & $8.76 \pm 1.06^{\mathrm{b}}$ & $10.17 \pm 2.01^{\mathrm{c}}$ & $5.51 \pm 1.21^{\mathrm{d}}$ & $* * *$ \\
SD (mm) & $9.91 \pm 1.88^{\mathrm{a}}$ & $6.99 \pm 0.80^{\mathrm{b}}$ & $8.06 \pm 1.49^{\mathrm{c}}$ & $4.55 \pm 0.95^{\mathrm{d}}$ & $* * *$ \\
Weight (g) & $1.01 \pm 0.51^{\mathrm{a}}$ & $0.46 \pm 0.21^{\mathrm{b}}$ & $0.82 \pm 0.16^{\mathrm{c}}$ & $0.15 \pm 0.25^{\mathrm{d}}$ & $* * *$ \\
Daily growth (g) & 0.02 & 0.01 & 0.01 & 0 & - \\
Survival rate $(\%)$ & 100 & 100 & 100 & 76 & - \\
\hline
\end{tabular}

$\overline{a, b, c, d}$ Lowercase letters indicate significant differences (Tukey's HSD; $p<0.01$ ) of examined variables between diets. Daily growth: (mean final weight-mean initial weight) $/ 56$ days. ${ }^{* * *}$ ANOVA; $p<0.001$.

\subsection{Indoor Polyculture Experiments}

Figure 5 and Table 3 present the weights of the juvenile L. canarium cocultured with different species at 18 and $28^{\circ} \mathrm{C}$. The weights of the groups cultured at $18^{\circ} \mathrm{C}$ were between $0.36 \pm 0.1 \mathrm{~g}$ (control, monoculture without sand) to $1.78 \pm 0.32 \mathrm{~g}$ (coculture with tilapia) (Table 3). All groups significantly differed from the control group with respect to weight $\left(p<0.05 ;\right.$ Table 3). The weights of the groups cultured at $28^{\circ} \mathrm{C}$ were $1.36 \pm 0.36 \mathrm{~g}$ (control, monoculture without sand) to $2.59 \pm 0.73 \mathrm{~g}$ (coculture with tilapia) (Table 3). Coculture with tilapia showed the highest weights at 18 and $28^{\circ} \mathrm{C}$. Except for the group that was cocultured with shrimp, all groups significantly differed from the control group with respect to weight $(p<0.05$; Table 3$)$. The survival rate $(\%)$ of the groups cultured at $18{ }^{\circ} \mathrm{C}$ were 81 (control, monoculture without sand) to 99 (coculture with abalone) (Table 3). The survival rate (\%) of the groups cultured at $28^{\circ} \mathrm{C}$ was 95 (coculture with purple sea urchin) and 96 (coculture with purple sea urchin) to 100 (other groups) (Table 3). In indoor polyculture experiments, we found that (1) at high temperature; (2) with bottom sand; and (3) coculture with other organisms, there are obvious benefits in growth and survival rate. Although bottom sand is a significant benefit to L. canarium, coculture with purple sea urchin, collector urchin, and abalone can achieve similar results with bottom sand. It has the best performance when it is cocultured with tilapia. We observed the obvious feces deposited in the bottom when cocultured with tilapia, which is presumed to be beneficial to the feeding of L. canarium, thus directly improving the growth. Additionally, it was no significant benefit when cocultured with shrimp. We observed that the shrimp often disturbs the feeding of L. canarium. In the high-temperature group $\left(28^{\circ} \mathrm{C}\right)$, the shrimp is more active and directly disturbs, and competes with L. canarium to feed the biological detritus. Therefore, it directly affects the growth of L. canarium. 


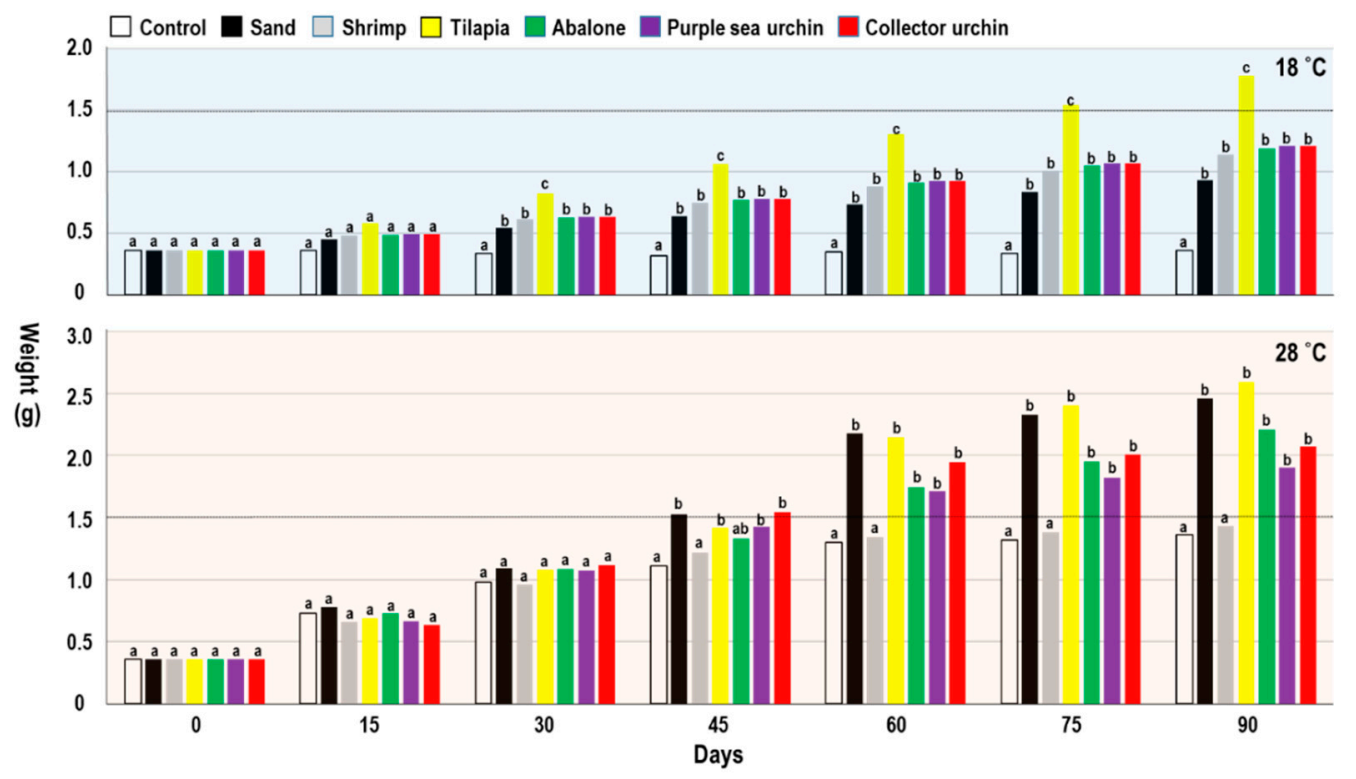

Figure 5. Laevistrombus canarium. Indoor polyculture experiments. Mean ( $\pm \mathrm{sd})$ weight of juveniles at various periods of coculture treatments (control, sand, cocultured with shrimp, tilapia, abalone, purple sea urchin, or collector urchin) at two temperature regimes $\left(18,28^{\circ} \mathrm{C}\right)$. Different letters indicate statistically significant differences (Tukey's HSD; $p<0.05$ ) between coculture treatments at each sampling day (0 to 90th day post-initiation of the experiment).

Table 3. Laevistrombus canarium. Mean ( \pm sd) of weight, shell length, shell width, shell depth, survival rate, and daily growth rate of juveniles after 90 days of coculture treatments (control, sand, cocultured with shrimp, tilapia, abalone, purple sea urchin, or collector urchin) at two temperature regimes $\left(18,28^{\circ} \mathrm{C}\right)$.

\begin{tabular}{|c|c|c|c|c|c|c|c|c|}
\hline $18^{\circ} \mathrm{C}$ & Control & Sand & Shrimp & Tilapia & Abalone & PU & CU & $p$ \\
\hline $\mathrm{SL}(\mathrm{mm})$ & $18.17 \pm 1.76^{a}$ & $18.00 \pm 2.86^{a}$ & $18.77 \pm 2.32^{\mathrm{a}}$ & $22.54 \pm 2.47^{b}$ & $20.09 \pm 1.42^{c}$ & $20.48 \pm 1.58^{c}$ & $20.11 \pm 1.46^{c}$ & $* * *$ \\
\hline $\mathrm{SW}(\mathrm{mm})$ & $8.85 \pm 0.85^{\mathrm{a}}$ & $9.10 \pm 1.67^{a b}$ & $9.66 \pm 1.26^{c}$ & $11.71 \pm 1.22^{\mathrm{d}}$ & $9.48 \pm 0.65^{b c}$ & $10.03 \pm 0.90^{\mathrm{cd}}$ & $9.37 \pm 0.91^{\mathrm{cb}}$ & $* * *$ \\
\hline $\mathrm{SD}(\mathrm{mm})$ & $6.81 \pm 0.66^{\mathrm{a}}$ & $7.41 \pm 1.32^{b}$ & $8.08 \pm 1.07^{c}$ & $9.06 \pm 1.13^{\mathrm{d}}$ & $7.40 \pm 0.41^{\mathrm{e}}$ & $7.48 \pm 0.69^{\mathrm{e}}$ & $7.78 \pm 0.65^{\text {ce }}$ & $* * *$ \\
\hline Weight (g) & $0.36 \pm 0.1^{\mathrm{a}}$ & $0.93 \pm 0.4^{\mathrm{b}}$ & $1.14 \pm 0.42^{c}$ & $1.78 \pm 0.32^{\mathrm{d}}$ & $1.19 \pm 0.12^{c}$ & $1.21 \pm 0.28^{c}$ & $1.21 \pm 0.34^{c}$ & $* * *$ \\
\hline Daily growth (g) & 0.00 & 0.01 & 0.01 & 0.02 & 0.01 & 0.01 & 0.01 & - \\
\hline Survival rate $(\%)$ & 81 & 88 & 96 & 92 & 99 & 95 & 96 & - \\
\hline $28^{\circ} \mathrm{C}$ & Control & Sand & Shrimp & Tilapia & Abalone & PU & $\mathrm{CU}$ & $p$ \\
\hline $\mathrm{SL}(\mathrm{mm})$ & $25.75 \pm 2.49^{a}$ & $30.45 \pm 4.01^{b}$ & $25.57 \pm 3.52^{\mathrm{a}}$ & $30.52 \pm 4.11^{b}$ & $29.95 \pm 2.76^{b c}$ & $28.37 \pm 2.32^{d}$ & $28.97 \pm 2.23^{\mathrm{cd}}$ & $* * *$ \\
\hline $\mathrm{SW}(\mathrm{mm})$ & $13.13 \pm 1.27^{\mathrm{a}}$ & $15.75 \pm 2.24^{b}$ & $12.93 \pm 1.80^{\mathrm{a}}$ & $15.67 \pm 2.16^{\mathrm{bc}}$ & $15.74 \pm 1.20^{b c}$ & $14.61 \pm 1.32^{\mathrm{d}}$ & $14.97 \pm 1.21 \mathrm{~cd}$ & $* * *$ \\
\hline $\mathrm{SD}(\mathrm{mm})$ & $10.46 \pm 1.05^{a}$ & $12.5 \pm 1.86^{\mathrm{b}}$ & $10.28 \pm 1.48^{a}$ & $12.51 \pm 1.88^{b}$ & $12.35 \pm 0.78^{b c}$ & $11.49 \pm 1.06^{\mathrm{d}}$ & $11.94 \pm 1.01^{\mathrm{bcd}}$ & $* * *$ \\
\hline Weight (g) & $1.36 \pm 0.36^{\mathrm{a}}$ & $2.46 \pm 0.59^{b}$ & $1.43 \pm 0.61^{\mathrm{a}}$ & $2.59 \pm 0.73^{b}$ & $2.21 \pm 0.53^{c}$ & $1.9 \pm 0.44^{\mathrm{d}}$ & $2.07 \pm 0.58^{\mathrm{cd}}$ & $* * *$ \\
\hline Daily growth (g) & 0.01 & 0.02 & 0.01 & 0.03 & 0.02 & 0.02 & 0.02 & - \\
\hline Survival rate $(\%)$ & 100 & 100 & 100 & 100 & 100 & 95 & 96 & - \\
\hline
\end{tabular}

$\mathrm{a}, \mathrm{b}, \mathrm{c}, \mathrm{d}, \mathrm{e}$ Lowercase letters indicate significant differences (Tukey's HSD; $p<0.05$ ) between coculture treatments on the 90th day post-initiation of the experiment. Daily growth: (mean final weight-mean initial weight)/90 days). ${ }^{* * *}$ ANOVA; $p<0.001$.

\subsection{Outdoor Polyculture Experiments}

The outdoor polyculture experiment could be separated into the low-water-temperature period (0-210 days) and high-water-temperature period (210-270 days). The weights of the juvenile L. canarium cocultured outdoor with different species are shown in Figure 6 and Table 4 . The weights were $5.18 \mathrm{~g}$ to $10.11 \mathrm{~g}$ (Table 4). Except for the group cocultured with shrimp, all coculture groups significantly differed from the control group with respect to weight $(p<0.05$; Table 4$)$. The survival rate $(\%)$ of the outdoor groups was 61 to 92 (Table 4). In outdoor polyculture experiments, we found some consistent results with indoor polyculture experiments. No significant difference among the groups was found in the low-temperature period (below $18{ }^{\circ} \mathrm{C}$ ). 


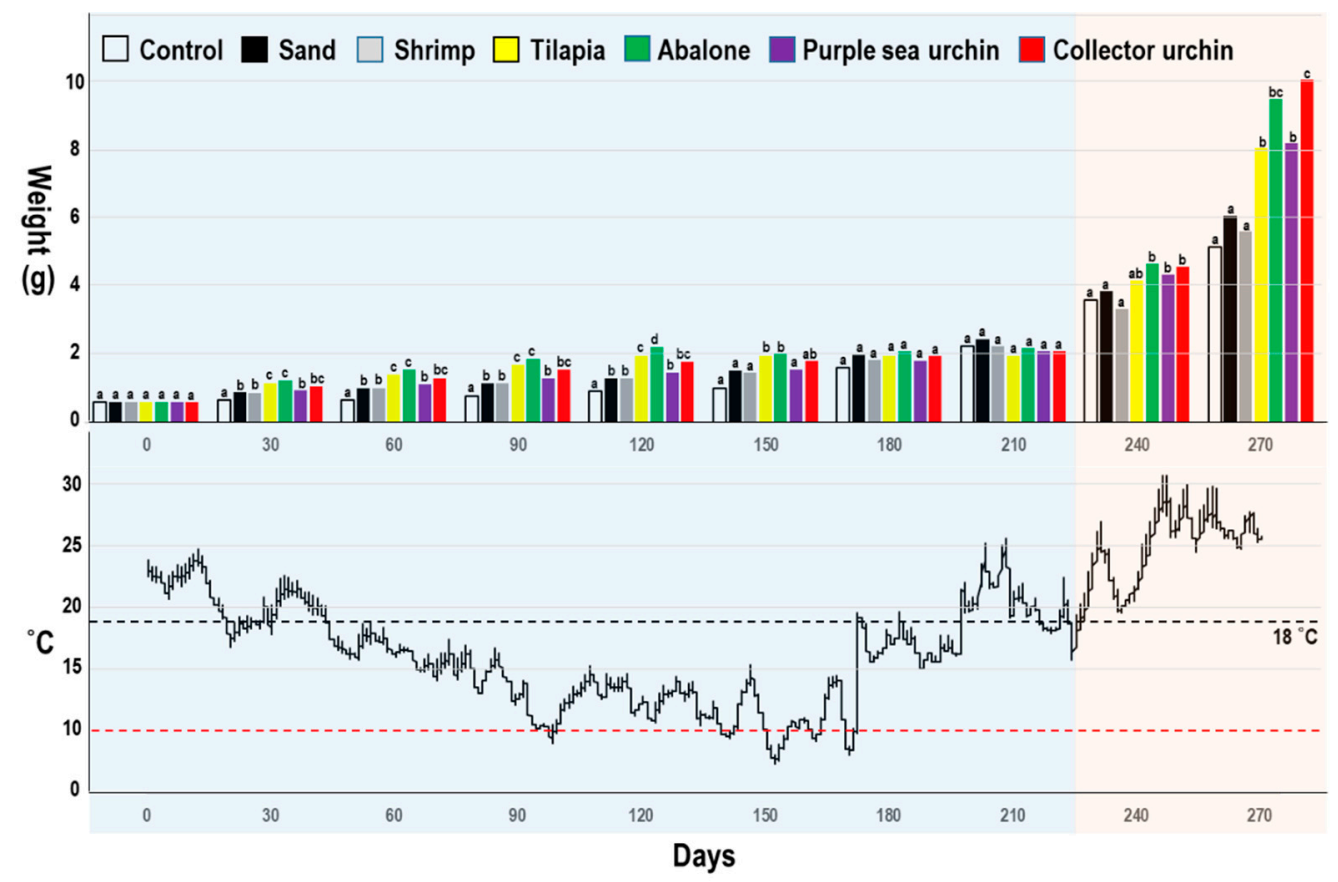

Figure 6. Laevistrombus canarium. Outdoor polyculture experiments. Mean $( \pm \mathrm{sd})$ weight of juveniles at various periods ( 0 to 270 days post initiation of the experiment) coculture treatments (control, sand, cocultured with shrimp, tilapia, abalone, purple sea urchin, or collector urchin). Mean daily outdoors water temperature values during the experimental period. Different letters indicate statistically significant differences (Tukey's HSD; $p<0.05$ ) between coculture treatments at each sampling day ( 0 to the 270 th day post-initiation of the experiment).

Table 4. Laevistrombus canarium. Mean ( \pm sd) of weight, shell length, shell width, shell depth, survival rate, and daily growth rate of juveniles after 270 days of coculture treatments (control, sand, cocultured with shrimp, tilapia, abalone, purple sea urchin, or collector urchin) at outdoors water temperature.

\begin{tabular}{|c|c|c|c|c|c|c|c|c|}
\hline Parameter & Control & Sand & Shrimp & Tilapia & Abalone & PU & $\mathrm{CU}$ & $p$ \\
\hline $\mathrm{SL}(\mathrm{mm})$ & $40.70 \pm 6.05^{\mathrm{a}}$ & $42.89 \pm 4.23^{b}$ & $39.97 \pm 3.93^{a}$ & $47.49 \pm 3.95^{c}$ & $49.42 \pm 3.38^{\mathrm{cd}}$ & $48.35 \pm 3.73^{c}$ & $50.90 \pm 3.34^{\mathrm{d}}$ & $* * *$ \\
\hline $\mathrm{SW}(\mathrm{mm})$ & $20.24 \pm 3.38^{a}$ & $22.07 \pm 2.31^{b}$ & $20.61 \pm 2.34^{a b}$ & $24.08 \pm 3.05^{c}$ & $25.68 \pm 3.27^{d}$ & $24.53 \pm 3.01 \mathrm{~cd}$ & $27.28 \pm 3.44^{\mathrm{e}}$ & $* * *$ \\
\hline $\mathrm{SD}(\mathrm{mm})$ & $16.45 \pm 2.49^{a}$ & $17.75 \pm 1.94^{b}$ & $16.75 \pm 1.93^{a}$ & $19.50 \pm 2.36^{c}$ & $20.31 \pm 1.71^{\mathrm{cd}}$ & $19.79 \pm 1.64^{c}$ & $21.06 \pm 1.72^{d}$ & $* * *$ \\
\hline Weight (g) & $5.18 \pm 2.57^{\mathrm{a}}$ & $6.10 \pm 2.31^{\mathrm{a}}$ & $5.63 \pm 1.82^{\mathrm{a}}$ & $8.09 \pm 2.50^{b}$ & $9.54 \pm 2.39^{c}$ & $8.23 \pm 1.92^{b}$ & $10.11 \pm 2.28^{c}$ & $* * *$ \\
\hline Daily growth (g) & 0.02 & 0.03 & 0.02 & 0.03 & 0.04 & 0.03 & 0.04 & - \\
\hline Survival rate $(\%)$ & 76 & 92 & 61 & 86 & 84 & 82 & 88 & - \\
\hline
\end{tabular}

$\mathrm{a}, \mathrm{b}, \mathrm{c}, \mathrm{d}, \mathrm{e}$ Lowercase letters indicate significant differences (Tukey's HSD; $p<0.05$ ) between coculture treatments at 270th day post initiation of the outdoor polyculture experiment. Daily growth: (mean final weight-mean initial weight) $/ 270$ days). ${ }^{* * *}$ ANOVA; $p<0.001$.

\section{Discussion}

The food preferences of gastropods depend on the habitat and availability of a particular species as food [12-14]. Herbivorous gastropods mainly live on macroalgae, including green, red, and brown algae $[15,16]$. Several studies have reported that L. canarium is widely distributed in the seagrass bed ecosystem of Indian and Pacific regions [17-20]. Seagrass leaves provide a place for planktonic organisms to settle. When they settle on seagrass leaves, they are called epiphytes. Algae are the most abundant and diverse group to colonize seagrass leaves. Algal epiphytes substantially contribute to the primary productivity of the ecosystem (20-60\%) and form the base of many food webs within seagrass communities. In field observations, L. canarium mainly grazed on epiphytes occurring on seagrass $(46.67 \%)$, on the sediment surface $(40 \%)$, and on macroalgae $(13.33 \%)$ [3]. The food items found in the conch stomach included diatoms, detritus, foraminifera, seagrass and macroalgae fragments, sand particles, and shell fragments [3]. The three main types of food 
for L. canarium are diatoms, sand particles, and detritus [3]. In this study, commercial tilapia feed ( $24 \%$ protein) and sea cucumber feed (34\% protein) were used in the preliminary diets test, however, we did not observe active feeding behavior. Consequently, it is more likely that diatoms and other biological detritus derived from feed could be their main source of nutrients. Therefore, polyculture groups grew faster than the monoculture group, which further implies that L. canarium might not directly benefit from the feed.

The food digestibility of adult L. canarium is between 55.21 and $74.75 \%$, which is lower than that of other herbivorous gastropods [4,9]. The gastric content of L. canarium is $20-30 \%$ in volume, and the debris that cannot and can provide energy comprising 45-60 and $7-15 \%$ of gastric content, respectively. These findings indicate that the proportion of sand is higher in the stomach content of L. canarium [4,9]. In this study, the growth rate of the monoculture without sand group at the two temperatures was significantly lower than in that of the monoculture with sand group (Table 3 ). This finding indicated that $L$. canarium itself could not effectively cut and grind food by itself. The ingestion of sand helps in its digestion and absorption. It is worth mentioning that we found L. canarium cocultured with other organisms could grow well or even better than those without the bottom sand (Tables 3 and 4). This means that the bottom sand could theoretically provide a good source of nutrients for digestion, but it is not critically necessary. Furthermore, the coculture of L. canarium without the substrates could be practically valuable since the accumulation of excessive food residues in the substrates could easily lead to death.

After metamorphosis, juvenile L. canarium becomes benthic grazers. It directly consumes algal epiphytes and cannot eat large seaweed alone [2]. The proportion of diatoms $(44.21 \%)$ was the highest in its stomach, followed by those of sand $(30.08 \%)$, detritus $(15.6 \%)$, and seaweed fragments $(8.55 \%)$ [4,9]. Powdered seaweeds have been used as nutrition sources for raising aquatic benthic animals (such as sea cucumber and mollusks) in hatcheries [21-24]. However, the group fed with kelp powder had the lowest survival and growth rates not only in the post-metamorphosis juvenile but also in $10 \mathrm{~mm}$ juvenile samples. This finding indicated that the kelp powder could not be effectively digested (high fiber content; $14 \%$ crude fiber) or provide complete nutrition to juveniles (low protein content; 12\% crude protein) (Figures 3 and 4). In the initial diet experiment (post-metamorphosis juvenile), the group fed with natural diatoms had a good growth rate in the first 30 days, similar to the flow-water method (Figure 3). For the $10 \mathrm{~mm}$ juvenile, the group fed with sea cucumber feed had a similar growth rate similar to the flow-water method. These findings indicate that natural diatoms were a favorable nutrition source in the first 30 days but did not provide adequate nutrition to L. canarium that were bigger in size (>10 mm; Figure 4). Sea cucumber feed was a favorable nutrition source in the later 30 days (Figure 4). A good feeding method is to use natural diatoms for the first 30 days before switching to sea cucumber feed. However, this study found the flow water method could increase the growth and survival rate of L. canarium (Figures 3 and 4). Organic debris from the fish pool can provide complete development nutrition and can effectively form a commercial breeding method. We successfully used this flow-water to culture more than 300 thousand juveniles in a 200 tons pool in Aqua Center (Figure 2I).

This study proposes the polyculture and flow water method from a fish pool to provide the source of food for L. canarium, but it is necessary to pay attention to the temperature and salinity factors on the L. canarium. In tropical to subtropical regions, the temperature and salinity of land-based saltwater aquaculture are usually $15-30{ }^{\circ} \mathrm{C}$ and $15-35 \%$, respectively. Substantial salinity fluctuations due to heavy rains are common in saltwater ponds $[25,26]$. Salinity often plays a major role in determining the distribution of many marine organisms, primarily because of its effects on many physiological and behavioral processes [27]. Temperature is a factor that limits the distribution of marine animals, affects their activity levels, and disrupts their energy balance [28]. Most aquatic organisms cannot adjust their body temperature according to the surrounding environment; thus, most physiological and biochemical processes depend on the ambient temperature [29,30]. In our preliminary 
study, L. canarium was cultured in saltwater ponds throughout the year (at a temperature of $8-32{ }^{\circ} \mathrm{C}$ and a salinity level of $15-40 \%$ ).

The growth rate of juvenile $L$. canarium is mainly dependent on the water temperature. In long-term outdoor experiments, we observed that the growth rate of L. canarium gradually increased with an increase in the water temperature (Figure 6). Even when the temperature is lower, the L. canarium shows lower growth and higher mortality, but they are still in the range that juvenile L. canarium can survive. Although northern Taiwan is a subtropical region, the water temperature of the land-based tanks in winter is sometimes less than $10{ }^{\circ} \mathrm{C}$. When we check the survival on the 150th day and the 180th day, we found that a water temperature of less than $10{ }^{\circ} \mathrm{C}$ might cause death (Figure 6). At a low water temperature, the survival and growth rates of L. canarium were significantly decreased. Hassan et al. [4] reported that the most favorable temperature range for feeding and digestion is $26-30{ }^{\circ} \mathrm{C}$ for sub-adults $L$. canarium. The order of feeding and digestion rates was $26,30,34$, and $22{ }^{\circ} \mathrm{C}$, and these rates were significantly higher at $34^{\circ} \mathrm{C}$ than at $22{ }^{\circ} \mathrm{C}$. These results reflect the natural habitat of L. canarium and its adaptability to high temperatures $\left(28-30^{\circ} \mathrm{C}\right)$ [7].

We examined the tolerance of early life stages of L. canarium to low salinity levels and found no significant difference among the survival rates of pelagic larvae exposed to salinity levels of 25,30 , and $35 \%$. Similar results were found in benthic juveniles; however, they exhibited increased tolerance to lower salinity levels $(20 \%)$ (Table 1$)$. The suitable salinity level for juvenile dog conch is between 20 and $35 \%$, indicating a wide range that is similar or better than those for sea urchins and sea cucumbers [31-34]. It means that the flow-water method from aquaculture ponds to provide early food sources for L. canarium has practical potential, even the salinity of the land-based ponds being more susceptible than natural seawater.

In this study, we found sand could be used for providing growth substrate of biofilms and diatoms (cultured with sand), or feed on natural sedimentary debris and diatoms (cultured without sand as the control) but also on feces and residual bait from other cultured organisms (cocultured). Although we did not analyze stomach content or stable isotopes, L. canarium grows better when they coculture with other organisms (Figures 5 and 6). When the water temperature was $28{ }^{\circ} \mathrm{C}$, the growth rates of the groups of polyculture (except whiteleg shrimp) were higher than the monoculture groups with sand. These findings indicated that fecal and residual nutrients from the aforementioned species could be effectively utilized by L. canarium even when sand is absent (Figures 5 and 6). Although small abalone, collector urchin, and purple sea urchin are benthic species, they exert no negative effects on polyculture with L. canarium (Figures 5 and 6). In addition, whiteleg shrimp affected L. canarium negatively, reducing their growth rate (Tables 3 and 4 ). One possible reason is that $L$. canarium feeds on biofilms as a grazer and has competition with the shrimps; the shrimp often disturbs the feeding of L. canarium, which is why the growth rates in this combination were significantly worse than in the others. In the later period, we found whiteleg shrimp grow faster than L. canarium, and the large size shrimp even cause many L. canarium deaths (Table 4). While this work has shown that shrimp might not be a suitable species to coculture with L. canarium, it is still likely to coculture L. canarium with shrimps in different pools or net cages. Further study is necessary to show the high potentials by using organic debris from shrimp pools (e.g., biofloc method) [35].

In commercial aquaculture, approximately $50-70 \%$ of the operational cost is spent on feed [36,37]. Thus, how to reusing residual feed and organic debris and generating less wastewater is critically important $[10,38,39]$. In IMTA, one kind of polyculture method, the uneaten feed and waste of one species are collected and converted into feed, fertilizer, and energy for another species [40-44]. For example, large organic solids are generated from feed waste or feces and can be consumed by deposit feeders such as sea urchins and sea cucumbers [32,38,39]. Although sea urchins and sea cucumbers are favorable IMTA species, they have mainly been used in marine cages. Some land-based saltwater aquaculture techniques (e.g., earth ponds) are unsuitable for sea urchins and sea cucumbers $[31,32,37]$. 
In this study, the polyculture and the water-flow method show high benefits in L. canarium production. The high growth rate and adaption of L. canarium are advantageous in tropical and subtropical IMTA. The findings revealed that $L$. canarium could efficiently adapt to different environmental conditions and thus can be a favorable IMTA species. We propose L. canarium as a new favorable IMTA species that can be coculture with abalone and sea urchins in seawater or used in land-based saltwater aquaculture (e.g., saltwater tilapia).

\section{Conclusions}

This study examined the effectiveness of different diets to grow larvae and juveniles of dog conch Laevistrombus canarium and also tested the feasibility of its co-culture with other marine species. We developed a novel polyculture and water-flow method for mass production of this species. The suitable salinity range and diets were determined in the early life stage of L. canarium. We found that the polyculture system without substrates is possible for juveniles. In addition, water temperature is the most crucial factor for its growth and survival since it could die if the water is colder than $10^{\circ} \mathrm{C}$. Our study reports that L. canarium is highly promising in IMTA cultivation.

Author Contributions: Conceptualization, Y.-C.C. and T.-H.H.; data curation, Y.-C.C. and C.-H.M.; formal analysis, Y.-C.C.; funding acquisition, T.-H.H.; investigation, Y.-C.C. and C.-H.M.; methodology, Y.-C.C. and T.-H.H.; project administration, T.-H.H.; resources, Y.-C.C. and T.-H.H.; software, Y.-C.C. and H.-T.L.; supervision, T.-H.H.; validation, Y.-C.C. and T.-H.H.; visualization, Y.-C.C., H.-T.L. and T.-H.H.; writing-original draft, Y.-C.C. and T.-H.H.; writing-review and editing, T.-H.H. and H.-T.L. All authors have read and agreed to the published version of the manuscript.

Funding: This work was supported by grants from the Center of Excellence for the Oceans (National Taiwan Ocean University), which were financially supported by the Featured Areas Research Center Program within the framework of the Higher Education Sprout Project by the Ministry of Education, ROC (Taiwan). This work was also supported by 2018-2020 Ministry of Science and Technology, Taiwan (MOST107-2313-B-019-004, MOST108-2313-B-019-001, MOST109-2313-B-019-004) and Taiwan Ocean Conservation and Fisheries Sustainability Foundation (109toffrest001, 110toffrest001).

Institutional Review Board Statement: The study was conducted according to the guidelines of the Institutional Animal Care and Use Committee of National Taiwan Ocean University (NTOU).

Informed Consent Statement: Not applicable.

Data Availability Statement: The data presented in this study are available on request from the corresponding author.

Conflicts of Interest: The authors declare no conflict of interest.

\section{References}

1. Cob, Z.C.; Arshad, A.; Bujang, J.S.; Abd Ghaffar, M. Description and evaluation of imposex in Strombus canarium Linnaeus, 1758 (Gastropoda, Strombidae): A potential bio-indicator of tributyltin pollution. Environ. Monit. Assess. 2011, 178, 393-400. [CrossRef] [PubMed]

2. Cob, Z.; Arshad, A.; Sidik, B.J.; Nurulhusna, W.; Mazlan, A. Feeding behaviour and stomach content analysis of Laevistrombus canarium (Linnaeus, 1758) from Merambong shoal, Johor. Malay. Nat. J. 2014, 66, 159-170.

3. Husna, W.N.W.H.; Mazlan, A.G.; Cob, Z.C. Ontogenetic changes in feeding and food preferences of the dog conch Laevistrombus canarium Linnaeus 1758 (Mollusca: Gastropoda) from Merambong shoal, Malaysia. Chin. J. Oceanol. Limnol. 2017, 35, 1230-1238. [CrossRef]

4. Hassan, W.N.H.W.; Sm, N.A.; Abd Ghaffar, M.; Cob, Z.C. Effects of temperature on food consumption of juveniles dog conch, Laevistrombus canarium (Linnaeus, 1758) in laboratory condition. J. Sustain. Sci. Manag. 2019, 14, 1-10.

5. Supratman, O.; Syamsudin, T.S. Behavior and feeding habit of dog conch (Strombus turturella) in South Bangka Regency, Bangka Belitung islands province. El-Hayah J. Biol. 2016, 6, 15-21. [CrossRef]

6. Ramses, R.; Syamsi, F.; Notowinarto, N. Length-weight relationship, growth patterns and sex ratio of dog conch Strombus Canarium Linnaeus, 1758 in the waters of Kota Batam. Omni-Akuatika 2019, 15, 19-29. [CrossRef]

7. Cob, Z.C.; Arshad, A.; Ghaffar, M.A.; Bujang, J.S.; Muda, W.W. Development and growth of larvae of the Dog Conch, Strombus canarium (Mollusca: Gastropoda), in the laboratory. Zool. Stud. 2008, 48, 1-11.

8. Cob, Z.C.; Arshad, A.; Idris, M.H.; Bujang, J.S.; Ghaffar, M.A. Sexual polymorphism in a population of Strombus canarium Linnaeus, 1758 (Mollusca: Gastropoda) at Merambong Shoal, Malaysia. Zool. Stud. 2008, 47, 318-325. 
9. Hassan, W.N.H.H.W.; Nurul-Amin, S.; Abd Ghaffar, M.; Cob, Z.C. Food consumption and assimilation of the adult dog conch Laevistrombus canarium (Linnaeus 1758) at different temperatures. Malays. J. Sci. 2019, 38, 98-114. [CrossRef]

10. Yokoyama, H. Growth and food source of the sea cucumber Apostichopus japonicus cultured below fish cages-Potential for integrated multi-trophic aquaculture. Aquaculture 2013, 372-375, 28-38. [CrossRef]

11. Yokoyama, H. Suspended culture of the sea cucumber Apostichopus japonicus below a Pacific oyster raft-Potential for integrated multi-trophic aquaculture. Aquac. Res. 2015, 46, 825-832. [CrossRef]

12. Steinberg, P.D. Feeding Preferences of Tegula Funebralis and Chemical Defenses of Marine Brown Algae. Ecol. Monogr. 1985, 55, 333-349. [CrossRef]

13. Qi, Z.; Liu, H.; Li, B.; Mao, Y.; Jiang, Z.; Zhang, J.; Fang, J. Suitability of two seaweeds, Gracilaria lemaneiformis and Sargassum pallidum, as feed for the abalone Haliotis discus hannai Ino. Aquaculture 2010, 300, 189-193. [CrossRef]

14. Angell, A.R.; Pirozzi, I.; de Nys, R.; Paul, N.A. Feeding Preferences and the Nutritional Value of Tropical Algae for the Abalone Haliotis asinina. PLoS ONE 2012, 7, e38857. [CrossRef]

15. Iken, K. Feeding ecology of the Antarctic herbivorous gastropod Laevilacunaria antarctica Martens. J. Exp. Mar. Biol. Ecol. 1999, 236, 133-148. [CrossRef]

16. Chikaraishi, Y.; Kashiyama, Y.; Ogawa, N.O.; Kitazato, H.; Ohkouchi, N. Metabolic control of nitrogen isotope composition of amino acids in macroalgae and gastropods: Implications for aquatic food web studies. Mar. Ecol. Prog. Ser. 2007, 342, 85-90. [CrossRef]

17. Cob, Z.; Bujang, J.; Ghaffar, M.; Arshed, A. Diversity and population structure characteristics of Strombus (Mesogastropod, Strombidae) in Johor Straits. Nat. Resour. Util. Environ. Preserv. Issues Chall. 2005, 2, 198-205.

18. Abbott, R.T. The genus Strombus in the Indo-pacific. Indo-Pac. Mollusca 1960, 1, 33-146.

19. Amini, S.; Pralampita, W. Pendugaan pertumbuhan beberapa parameter biologi gonggong (Strombus canarium) di perairan pantai Pulau Bintan-Riau. J. Pen. Perikan. Laut 1987, 41, 29-35.

20. Erlambang, T. Some biology and ecology aspects of dog conch (Strombus canarium) based on a year round study in Riau province, Indonesia. J. Xiamen Fish. Coll. 1996, 18, 33-41.

21. Fleurence, J.; Morançais, M.; Dumay, J.; Decottignies, P.; Turpin, V.; Munier, M.; Garcia-Bueno, N.; Jaouen, P. What are the prospects for using seaweed in human nutrition and for marine animals raised through aquaculture? Trends Food Sci. Technol. 2012, 27, 57-61. [CrossRef]

22. Xia, S.; Yang, H.; Li, Y.; Liu, S.; Zhou, Y.; Zhang, L. Effects of different seaweed diets on growth, digestibility, and ammonia-nitrogen production of the sea cucumber Apostichopus japonicus (Selenka). Aquaculture 2012, 338-341, 304-308. [CrossRef]

23. Xia, S.; Zhao, P.; Chen, K.; Li, Y.; Liu, S.; Zhang, L.; Yang, H. Feeding preferences of the sea cucumber Apostichopus japonicus (Selenka) on various seaweed diets. Aquaculture 2012, 344-349, 205-209. [CrossRef]

24. Davis, M.; Cassar, V. Queen conch aquaculture: Hatchery and nursery phases. J. Shellfish Res. 2020, 39, 731-810. [CrossRef]

25. Xiao, B.C.; Li, E.C.; Du, Z.Y.; Jiang, R.L.; Chen, L.Q.; Yu, N. Effects of temperature and salinity on metabolic rate of the Asiatic clam Corbicula fluminea (Müller, 1774). SpringerPlus 2014, 3, 455. [CrossRef]

26. Moussa, R.M. The potential impacts of low and high salinities on salinity tolerance and condition index of the adult pearl oyster Pinctada imbricata radiata (Leach, 1814). J. Basic Appl. Zool. 2018, 79, 12. [CrossRef]

27. Delorme, N.J.; Sewell, M.A. Temperature and salinity: Two climate change stressors affecting early development of the New Zealand sea urchin Evechinus chloroticus. Mar. Biol. 2014, 161, 1999-2009. [CrossRef]

28. Sobral, P.; Widdows, J. Effects of elevated temperatures on the scope for growth and resistance to air exposure of the clam Ruditapes decussatus (L.), from southern Portugal. Sci. Mar. 1997, 61, 163-171.

29. Resgalla, C., Jr.; Brasil, E.d.S.; Salomão, L.C. The effect of temperature and salinity on the physiological rates of the mussel Perna perna (Linnaeus 1758). Braz. Arch. Biol. Technol. 2007, 50, 543-556. [CrossRef]

30. Dame, R.F.; Kenneth, M.J. Ecology of Marine Bivalves: An Ecosystem Approach, 2nd ed.; Taylor \& Francis: Boca Raton, FL, USA, 2011.

31. Toral-Granda, V.; Lovatelli, A.; Vasconcellos, M. Sea cucumbers. In A Global Review of Fisheries and Trade; FAO Fisheries and Aquaculture Technical Paper. No. 516; FAO: Rome, Italy, 2008; p. 317.

32. Katow, H.; Okumura, S.; Sakai, Y.; Shibuya, C. Sea cucumber farming in Japan. In Echinoderm Aquaculture; Wiley: Hoboken, NJ, USA, 2015; pp. 287-316.

33. Metaxas, A. The effect of salinity on larval survival and development in the sea urchin Echinometra lucunter. Invertebr. Reprod. Dev. 1998, 34, 323-330. [CrossRef]

34. Montory, J.A.; Chaparro, O.R.; Pechenik, J.A.; Diederich, C.M.; Cubillos, V.M. Impact of short-term salinity stress on larval development of the marine gastropod Crepipatella fecunda (Calyptraeidae). J. Exp. Mar. Biol. Ecol. 2014, 458, 39-45. [CrossRef]

35. Poli, M.A.; Legarda, E.C.; de Lorenzo, M.A.; Pinheiro, I.; Martins, M.A.; Seiffert, W.Q.; do Nascimento Vieira, F. Integrated multitrophic aquaculture applied to shrimp rearing in a biofloc system. Aquaculture 2019, 511, 734274. [CrossRef]

36. Robinson, G.; Slater, M.J.; Jones, C.L.W.; Stead, S.M. Role of sand as substrate and dietary component for juvenile sea cucumber Holothuria scabra. Aquaculture 2013, 392-395, 23-25. [CrossRef]

37. Heflin, L.E.; Makowsky, R.; Taylor, J.C.; Williams, M.B.; Lawrence, A.L.; Watts, S.A. Production and economic optimization of dietary protein and carbohydrate in the culture of Juvenile Sea Urchin Lytechinus variegatus. Aquaculture 2016, 463, 51-60. [CrossRef] [PubMed] 
38. Hannah, L.; Pearce, C.M.; Cross, S.F. Growth and survival of California sea cucumbers (Parastichopus californicus) cultivated with sablefish (Anoplopoma fimbria) at an integrated multi-trophic aquaculture site. Aquaculture 2013, 406-407, 34-42. [CrossRef]

39. Yu, Z.; Zhou, Y.; Yang, H.; Hu, C. Bottom culture of the sea cucumber Apostichopus japonicus Selenka (Echinodermata: Holothuroidea) in a fish farm, southern China. Aquac. Res. 2014, 45, 1434-1441. [CrossRef]

40. Chopin, T. Integrated multi-trophic aquaculture-ancient, adaptable concept focuses on ecological integration. Glob. Aquac. Advocate 2013, 16, 16-19.

41. Neori, A.; Shpige, M.; Guttman, L.; Israel, A. Development of Polyculture and Integrated Multi-Trophic Aquaculture (IMTA) in Israel: A Review. Isr. J. Aquac.-Bamidgeh 2017, 69, 20874.

42. Fang, J.; Zhang, J.; Xiao, T.; Huang, D.; Liu, S. Integrated multi-trophic aquaculture (IMTA) in Sanggou Bay, China. Aquac. Environ. Interact. 2016, 8, 201-205. [CrossRef]

43. Biswas, G.; Kumar, P.; Ghoshal, T.K.; Kailasam, M.; De, D.; Bera, A.; Mandal, B.; Sukumaran, K.; Vijayan, K.K. Integrated multi-trophic aquaculture (IMTA) outperforms conventional polyculture with respect to environmental remediation, productivity and economic return in brackishwater ponds. Aquaculture 2020, 516, 734626. [CrossRef]

44. Shpigel, M.; Shauli, L.; Odintsov, V.; Ben-Ezra, D.; Neori, A.; Guttman, L. The sea urchin, Paracentrotus lividus, in an Integrated Multi-Trophic Aquaculture (IMTA) system with fish (Sparus aurata) and seaweed (Ulva lactuca): Nitrogen partitioning and proportional configurations. Aquaculture 2018, 490, 260-269. [CrossRef] 